\title{
PENGARUH JENJANG PENDIDIKAN DAN SKALA USAHA TERHADAP PENGGUNAAN INFORMASI AKUNTANSI PADA UMKM KECAMATAN PAMULANG KOTA TANGERANG SELATAN
}

\author{
Eka Kusuma Dewi ${ }^{1^{*}}$, Purwatiningsih $^{2}$ \\ Universitas Pamulang \\ eka.kusuma.dewi@gmail.com, ningsihkarno17@gmail.com
}

\begin{abstract}
One of the big problems of SMEs that happen in Indonesia is manual bookkeeping. Therefore, it leads to difficulty in calculating turnover, gross profit, and net profit, inhibiting SMEs from growing and scaling up the business. This study aims to observe and determine whether there is an influence of Education Level and Business Scale on the Use of Accounting Information in SMEs in Pamulang District Tangerang Selatan. The tests carried out show that the education level variable significantly affects and the business scale variable does not influence users of accounting information. Based on the $F$ test, it is known that the level of education and the scale of business together significantly affect users of accounting information. So it can be concluded that the results of this study indicate that the education level of the MSME actors affects the use of accounting information in their respective units.
\end{abstract}

Keywords: Accounting Information, Education Level, Business Scale, SMEs

\section{PENDAHULUAN}

UMKM Usaha Mikro Kecil dan Menengah adalah usaha perdagangan yang dikelola oleh badan usaha atau perorangan yang merujuk pada usaha ekonomi produktif sesuai dengan kriteria yang ditetapkan oleh Undang-Undang Nomor 20 Tahun 2008. (https://www.jurnal.id/id/blog/pengertian-jenis-dan-perkembangan-umkm-di-indonesia/ ). Tidak bisa dipungkiri, usaha Mikro, Kecil dan Menengah ( $\underline{\mathrm{UMKM}}$ ) di Indonesia merupakan salah satu penggerak utama perekonomian. Maka tak heran jika sektor UMKM terganggu maka ekonomi nasional juga terganggu. Menurut Badan Pusat Statistik (BPS) jumlah Usaha Mikro Kecil dan Menengah (UMKM) mencapai 64 juta. Angka tersebut mencapai 99,9 persen dari keseluruhan usaha yang beroperasi di Indonesia. ( Santia, 2020).

Jumlah Usaha Mikro Kecil dan Menengah (UMKM) di Indonesia terus bertambah setiap tahun. Di tahun 2018, jumlah pengusaha UMKM diprediksi mencapai 58,97 juta orang. Bahkan, angka ini diprediksi terus meningkat di tahun berikutnya seiring dengan kemajuan teknologi dan potensi sumber daya manusia yang semakin berkembang. Peningkatan jumlah UMKM ini membawa pengaruh yang cukup baik bagi perekonomian di Indonesia. Mulai dari penyerapan tenaga kerja hingga peningkatan produk domestik bruto yang cukup besar, yaitu mencapai 60,34 persen di tahun 2018. Dari sekian banyak permasalahan UMKM yang terjadi di Indonesia, berikut permasalahan yang sering terjadi pada UMKM di Indonesia :

\section{Minimnya Modal}

Permasalahan UKM paling utama adalah modal usaha yang terbatas. Akibatnya, para pengusaha tidak bisa menaikkan jumlah produksinya untuk mencapai omzet lebih banyak. 


\section{Distribusi Tidak Tepat}

Kurangnya channel untuk pendistribusian barang juga menjadi tantangan yang dihadapi oleh pelaku UMKM. Rekomendasi teman dan pemasaran dari mulut ke mulut bahkan menjadi channel favorit pelaku UMKM dalam memasarkan produknya.

\section{Pengelolaan Keuangan Tidak Efisien}

Pengelolaan keuangan yang tidak efisien akan membuat masalah. Salah satunya masalah yang dihadapi perihal keuangan yaitu adanya pengeluaran keuangan lebih besar dari pemasukan. Hal itu berarti bisnis Anda tidak menghasilkan pendapatan yang cukup dari pelanggan.

\section{Kurangnya Inovasi}

Pelaku UMKM diharapkan mampu untuk berpikir kritis sekaligus inovatif dalam memproduksi barang dan jasa. Meski barang yang ditawarkan sejenis, tetapi jika masing-masing memiliki perbedaan yang signifikan membuat konsumen mempunyai banyak pilihan.

\section{Belum Memaksimalkan Pemasaran Online}

Kurangnya pengetahuan sampai dengan adaptasi terhadap internet dan perkembangan teknologi yang dialami pelaku UMKM ini menjadi tantangan dan masalah yang harus dihadapi.

\section{Pembukuan Masih Manual}

Pembukuan termasuk dalam pengelolaan keuangan yang menjadi salah satu inti keberhasilan usaha. Kesulitan dalam memperhitungkan omset, laba kotor sampai dengan laba bersih karena pembukuan yang masih manual seringkali menghambat UMKM untuk bisa growth dan scale up bisnisnya.

Walaupun terkesan tata tertib, pembukuan untuk bisnis merupakan hal yang sepele, nyatanya dengan data pembukuanlah suatu perusahaan bisa mengukur keberhasilan dan merencanakan strategi perusahaan ke depannya.

\section{Manajemen Waktu}

Lebih dari 90 persen pemilik bisnis bekerja multitasker, Mereka bekerja menjadi pengusaha sekaligus pemilik bisnis kecil dan pengurus semua masalah bisnis kecil. Jika Anda tidak berusaha mengatur waktu sebaik mungkin, Anda akan mengalami kesulitan terkait dengan itu. Maka, buatlah daftar hal yang akan dilakukan "To Do List". Hal tersebut akan memudahkan para pemilik UMKM yang bekerja multitasker dalam mengatur waktu. Satu hal lagi, orang yang mengatur waktu dengan baik adalah orang yang membuat perbedaan.

\section{Tidak Memiliki Izin}

Permasalahan UMKM yang terakhir yaitu tidak adanya izin usaha resmi, sehingga menghambat laju usaha Anda. (Permana, 2020). Dari bahasan di atas, terlihat bahwa pembukuan yang masih manual, merupakan salah satu masalah terbesar untuk UMKM di Indonesia. Informasi akuntansi merupakan bagian yang terpenting dari seluruh informasi yang diperlukan manajemen terutama yang berhubungan dengan data keuangan. "Tujuan informasi akuntansi tersebut adalah memberikan petunjuk dalam memilih tindakan yang paling baik untuk mengalokasikan sumber daya yang langka pada aktivitas bisnis dan ekonomi". (Tambunan, 2019) "Oleh karena itu, perlu dilakukan upaya memetakan faktor- faktor yang mempengaruhi penggunaan informasi akuntansi sehingga pelaku UMKM dalam hal akuntansi, serta upaya perbaikannya mampu memanfaatkan informasi akuntansi yang ada, sehingga dapat meningkatkan kualitas pengambilan berbagai keputusan yang dibuatnya". (Andriani dan Zuliyati, 2015).

Terdapat beberapa variable yang mempengaruhi penggunaan informasi akuntansi, seperti yang dibuktikan dalam penelitian oleh Nirwana, A., \& Purnama, D. (2019) yang membuktikan bahwa ada pengaruh dari latar belakang pendidikan, skala usaha dan lama usaha terhadap penggunaan informasi akuntansi. Jenjang pendidikan adalah tahapan dasar yang ditetapkan berdasarkan tingkat perkembangan peserta didik, tujuan yang akan dicapai dan kemampuan yang dikembangkan (UU No. 20, 2003). Dan skala usaha merupakan kemampuan perusahaan dalam mengelola usahanya dengan melihat berapa jumlah karyawan yang dipekerjakan dan berapa besar pendapatan yang diperoleh perusahaan dalam satu periode akuntansi (Nicholls dan Holmes, 1988).

Beberapa penelitian yang mengangkat masalah yang serupa seperti Aufar (2013) yang 
membuktikan bahwa terdapat hubungan antara latar belakang pendidikan, ukuran usaha, lama usaha dan latar belakang pendidikan dari pemilik UMKM berpengaruh secara parsial dan simultan terhadap penggunaan informasi akuntansi pada UMKM. Begitu juga dengan penelitian Zulkarnnaeni, A. S., \& Rizki, N. C. (2019), juga membuktikan bahwa terdapat hubungan antara latar belakang pendidikan, ukuran perusahaan dan pelatihan akuntansi terhadap penggunaan informasi akuntansi. Dan Novianti, D., Mustika, I. W., \& Eka, L. H. (2018) yang membuktikan bahwa terdapat pengaruh antara jenjang pendidikan dan skala usaha terhadap penggunaan informasi akuntansi. Akan tetapi penelitian yang dilakukan oleh Sriwahyuni, et al. (2016) menghasilkan penelitian yang tidak membuktikan bahwa terdapat pengaruh antara latar belakang Pendidikan dan skala usaha terhadap penggunaan informasi akuntansi.

Dari latar belakang diatas, maka kami merumuskan masalah untuk penelitian ini sebagai berikut:

1. Apakah terdapat pengaruh antara jenjang Pendidikan terhadap penggunaan informasi akuntansi di UKM kecamatan Pamulang

2. Apakah terdapat pengaruh antara skala usaha terhadap penggunaan informasi akuntansi di UKM kecamatan Pamulang

3. Apakah jenjang Pendidikan dan skala usaha secara ber sama sama mempengaruhi penggunaan informasi akuntansi di UKM kecamatan Pamulang

\section{TINJAUAN PUSTAKA}

A. Unit Mikro Kecil Menengah (UMKM)

Kriteria usaha yang termasuk dalam UMKM sudah tertera dalam Undang Undang Nomer 20 tahun 2008, yaitu:

1. Usaha Mikro adalah usaha produktif milik orang perorangan dan/atau badan usaha perorangan yang memenuhi kriteria Usaha Mikro sebagaimana diatur dalam UndangUndang ini.

2. Usaha Kecil adalah usaha ekonomi produktif yang berdiri sendiri, yang dilakukan oleh orang perorangan atau badan usaha yang bukan merupakan anak perusahaan atau bukan cabang perusahaan yang dimiliki, dikuasai, atau menjadi bagian baik langsung maupun tidak langsung dari Usaha Menengah atau Usaha Besar yang memenuhi kriteria Usaha Kecil sebagaimana dimaksud dalam Undang-Undang ini.

3. Usaha Menengah adalah usaha ekonomi produktif yang berdiri sendiri, yang dilakukan oleh orang perorangan atau badan usaha yang bukan merupakan anak perusahaan atau cabang perusahaan yang dimiliki, dikuasai, atau menjadi bagian baik langsung maupun tidak langsung dengan Usaha Kecil atau Usaha Besar dengan jumlah kekayaan bersih atau hasil penjualan tahunan sebagaimana diatur dalam UndangUndang ini.

AdapunTujuan pemberdayaan Usaha Mikro, Kecil, dan Menengah:

a. mewujudkan struktur perekonomian nasional yang seimbang, berkembang, dan berkeadilan;

b. menumbuhkan dan mengembangkan kemampuan Usaha Mikro, Kecil, dan Menengah menjadi usaha yang tangguh dan mandiri; dan

c. meningkatkan peran Usaha Mikro, Kecil, dan Menengah dalam pembangunan daerah, penciptaan lapangan kerja, pemerataan pendapatan, pertumbuhan ekonomi, dan pengentasan rakyat dari kemiskinan.

Kriteria Usaha Mikro adalah sebagai berikut:

a) memiliki kekayaan bersih paling banyak Rp50.000.000,00 (lima puluh juta rupiah) tidak termasuk tanah dan bangunan tempat usaha; atau

b) memiliki hasil penjualan tahunan paling banyak Rp300.000.000,00 (tiga ratus juta rupiah). 
Kriteria Usaha Kecil adalah sebagai berikut:

a) memiliki kekayaan bersih lebih dari Rp50.000.000,00 (lima puluh juta rupiah) sampai dengan paling banyak Rp500.000.000,00 (lima ratus juta rupiah) tidak termasuk tanah dan bangunan tempat usaha; atau

b) memiliki hasil penjualan tahunan lebih dari Rp300.000.000,00 (tiga ratus juta rupiah) sampai dengan paling banyak Rp2.500.000.000,00 (dua milyar lima ratus juta rupiah).

Kriteria Usaha Menengah adalah sebagai berikut:

a) memiliki kekayaan bersih lebih dari Rp500.000.000,00 (lima ratus juta rupiah) sampai dengan paling banyak Rp10.000.000.000,00 (sepuluh milyar rupiah) tidak termasuk tanah dan bangunan tempat usaha; atau

b) memiliki hasil penjualan tahunan lebih dari Rp2.500.000.000,00 (dua milyar lima ratusjuta rupiah) sampai dengan paling banyak Rp50.000.000.000,00 (lima puluh milyar rupiah).

(undang undang No 20 tahun 2008)

Meski skala bisnis yang ditargetkan oleh bisnis UMKM tidak sebesar perusahaan kelas kakap, banyak orang yang nyaman berbisnis dalam level ini karena keunggulan yang ditawarkan pada bisnis usaha mikro, kecil dan menengah serta keunggulan tersebut sulit didapatkan di level bisnis raksasa. Salah satu keunggulan yang utama adalah kemudahan dalam mengadopsi inovasi dalam bisnis, terutama dalam bidang teknologi. Adopsi teknologi terbaru menjadi lebih mudah dilakukan untuk meningkatkan pertumbuhan bisnis UMKM karena tidak memiliki birokrasi yang berbelit dan sistem yang rumit. Selain kemudahan aplikasi teknologi, keunggulan dalam faktor hubungan antar karyawan karena lingkupnya lebih kecil, dan fleksibilitas untuk menyesuaikan bisnis dengan kondisi pasar yang dinamis. (Diakses pada 27 Oktober 2020 dari https://www.jurnal.id/id/blog/pengertian-jenis-dan-perkembangan-umkm-di-indonesia/.

B. Informasi Akuntansi

"Menurut (George and Wiliam, 2000), dalam (Nafsiah dan Birahma, 2019) informasi adalah suatu data yang tergarap yang menyebabkan dapat dijadikan bagian umum untuk menghasilkan suatu keputusan, dalam bidang usaha, informasi tersebut memiliki definisi yang jauh lebih berharga yakni sebagai pengetahuan umum untuk dilakukan pengambilan suatu keputusan, informasi usaha mendukung untuk memastikan suatu kesimpulan saat ini maupun di masa yang akan datang agar mencapai kehendak perusahaan".

Sedangkan akuntansi adalah seni pencatatan, penggolongan, pengikhtisaran, dan pelaporan atas suatu transaksi dengan cara sedemikian rupa, sistematis dari segi isi, dan berdasarkan standar yang diakui umum. Oleh karena itu, pihak yang berkepentingan atas perusahaan dapat mengetahui posisi keuangan perusahaan serta hasil operasi pada setiap waktu yang diperlukan, sehingga dapat mengambil maupun pemilihan dari berbagai tindakan alternative di bidang ekonomi. (Bahri 2016)

Sehingga, "Menurut (Bekaoui, 2000) dalam (Nafsiah dan Birahma, 2019), menyatakan bahwa informasi akuntansi merupakan suatu informasi kuantitatif berisikan entitas ekonomi yang berguna akan pengambilan kesimpulan ekonomi untuk memastikan pilihanpilihan di antaranya alternatif-alternatif berupa tindakan penggunaan informasi akuntansi tersebut buat perancangan strategis, pengamatan manajemen, serta pengamatan operasional".

"Belkaoui (2010) dalam Andriani dan Zuliyati (2015), mendefinisikan informasi akuntansi sebagai informasi kuantitatif tentang entitas ekonomi yang bermanfaat untuk pengambilan keputusan ekonomi dalam menentukan pilihan- pilihan dan alternatif-alternatif tindakan". Pengguna informasi akuntansi untuk perencanaan strategis, pengawasan manajemen dan pengawasan operasional

Masalah yang sering dihadapi oleh para pelaku UMKM salah satunya yaitu pengelolaan keuangan. Dampak dari diabaikannya pengelolaan keuangan mungkin tidak terlihat jelas, 
namun tanpa metode akuntansi yang efektif, usaha yang memiliki prospek untuk berhasil dapat menjadi bangkrut. "Masalah utama dalam pengembangan UMKM yaitu dinilai masih kurang memahami pengelolaan keuangan. Masih banyak pengusaha kecil yang belum melakukan pencatatan atas laporan keuangan usahanya dengan baik. Bahkan, ada juga yang tidak melakukan pen catatan. Para pengusaha kecil dan menengah biasanya hanya mengerjakan pembukuan sebatas pencatatan pendapatan dan pengeluaran saja. Akibatnya, laba bersih perusahaan sulit diketahui, sehingga pengajuan kredit di lembaga perbankan untuk modal usaha sulit diperoleh, dikarenakan sebagian besar dari pelaku UMKM memiliki keterbatasan-keterbatasan untuk menghasilkan laporan keuangan yang berkualitas"(Efriyenty,2020).

Adapun faktor faktor yang mempengaruhi penggunaan informasi akuntansi yang dibahas pada penelitian ini adalah:

\section{Jenjang Pendidikan}

"Kemampuan pemilik perusahaan sangat mempengaruhi persiapannya dan penggunaan informasi akuntansi. Kemampuan pemilik perusahaan kecil dan menengah dapat ditentukan dari pendidikan formal pemilik perusahaan. Tingkatan pendidikan formal pemilik perusahaan kecil dan menengah sangat mempengaruhi persiapannya dan penggunaan informasi akuntansi keuangan dan manajemen. Tingkatan pendidikan formal yang rendah (tingkat pendidikan sekolah dasar sampai dengan sekolah menengah umum) pada pemilik, akan menyebabkan rendahnya persiapan dan penggunaan informasi akuntansi dibandingkan tingkatan pendidikan formal yang tinggi (perguruan tinggi) pemilik. Ini sebabnya materi pengajaran akuntansi lebih tinggi diberikan diperguruan tinggi dibandingkan dengan pendidikan yang lebih rendah". (Astuti, 2014). "Jenjang pendidikan formal yang tertuang dalam (Depdiknas, 2012) yang menyatakan bahwa jenjang pendidikan formal terdiri atas pendidikan dasar, pendidikan menengah dan pendidikan tinggi. Jenis pendidikan mencakup pendidikan umum, kejuruan, akademik, profesi, vokasi, keagamaan dan khusus, jalur, jenis pendidikan yang diwujudkan dalam bentuk satuan pendidikan yang diselenggarakan oleh pemerintah daerah dan masyarakat". (Dian Efriyenty, 2020)

Dengan memakai variable jenjang Pendidikan diharapkan dapat ditemukan pengaruh terhadap penggunaan informasi akuntansi pada UMKM kecamatan Pamulang kota Tangerang Selatan. Sehingga dikemudian hari dapat ditemukan solusi untuk peningkatan kualitas UMKM kecamatan Pamulang secara umum.

\section{Skala Usaha}

Skala usaha merupakan kemampuan suatu perusahaan dalam mengelola usahanya berdasarkan jumlah karyawan dan pendapatan perusahaan dalam kurun waktu tertentu (Holmes, 2011). Semakin besar skala bisnisnya, semakin kompleks proses bisnisnya, dan kebutuhan akuntansi untuk kelangsungan bisnis semakin meningkat, sehingga informasi akuntansi dapat digunakan sebagai alat bantu pengambilan keputusan manajemen. Berdasarkan pengertian di atas skala usaha didefinisikan sebagai pengukuran kriteria perusahaan berdasarkan jumlah pekerja per hari baik pekerja tetap maupun tidak tetap dan jumlah pendapatan pada perusahaan yang akan mempengaruhi kemampuan dalam operasional yang dijalankan. (Sunaryo, 2020)

\section{METODE}

teknik pengumpulan data, sumber data, cara analisis data, uji korelasi, dan sebagainya,

\section{A. Populasi dan sampel}

Dalam penelitian ini, populasi yang digunakan adalah Usaha Kecil Menengah (UKM) di Kecamatan Pamulang Kota Tangerang Selatan Provinsi Banten. Menurut informasi yang didapat dari Dinas Koperasi dan Usaha Kecil dan Menengah Tangerang Selatan, jumlah UKM di wilayah ini sebanyak 2.215 unit. Jumlah sampel penelitian ditetapkan melalui model 
Solvin, teknik pengambilan sampel dengan teknik Convenience Sampling.

Persyaratan pengambilan sampel ditetapkan;

1. Terdaftar di Dinas Koperasi dan UKM Kota Pamulang Tangerang Selatan.

2. UMKM memiliki ijin usaha

3. UMKM memiliki nomor pokok wajib pajak

4. Memiliki struktur organisasi

5. Memiliki omset $\geq$ Rp 500.000,-/ hari atau Rp 10.000.000,-/ bulan

Penentuan jumlah atau ukuran sampel akan di tentukan dengan menggunakan rumus

Yamane dari Slovin (Efriyenty, 2020) sebagai berikut:

$$
\mathrm{n}=\frac{\mathrm{N}}{\mathrm{N} . \mathrm{d} 2+1} \text {. }
$$

Rumus 1 Slovin

\section{Keterangan:}

$\mathrm{N}=$

Ukuran

populasi

$\mathrm{n}=$

Ukuran

sampel

$\mathrm{d}=$ presisi (derajat ketelitian $=10 \%)$

\section{B. Variabel Penelitian}

Definisi operasional variabel adalah penentuan variabel sehingga menjadi variabel yang dapat diukur. Variabel penelitian di dalam penelitian ini terlihat sebagai berikut:

\begin{tabular}{|c|c|c|c|}
\hline Variabel & Definisi Variabel & Indikator & Skala \\
\hline $\begin{array}{l}\text { Penggun } \\
\text { aan } \\
\text { Informasi } \\
\text { Akuntans } \\
\text { i (Y) }\end{array}$ & $\begin{array}{l}\text { Proses yang menggunakan } \\
\text { informasi akuntansi yaitu } \\
\text { informasi operasi, akuntansi } \\
\text { manajemen dan akuntansi } \\
\text { keuangan (Wibowo dan } \\
\text { Elisabeth, 2015) }\end{array}$ & $\begin{array}{l}\text { Indikator penggunaan informasi } \\
\text { akuntansi mengacu pada } \\
\text { (Wibowodan Elisabeth, 2015): } \\
\text { 1. Statutory } \\
\text { ounting information. } \\
\text { Terdiri dari buku kas } \\
\text { masuk, buku kas keluar, buku } \\
\text { piutang, buku persediaan, } \\
\text { buku penjualan dan buku } \\
\text { pebelian. } \\
\text { 2. Budgetary Information. } \\
\text { Terdiri dari anggaran arus } \\
\text { kas, anggaran penjualan, } \\
\text { anggaran produksi } \\
\text { 3. Additional accounting } \\
\text { information } \\
\text { Terdiri dari laporan persediaan, } \\
\text { laporan gaji karyawan, dan }\end{array}$ & Likert \\
\hline
\end{tabular}




\begin{tabular}{|c|c|c|c|}
\hline & & laporan biaya produksi & \\
\hline $\begin{array}{l}\quad \text { Jenj } \\
\text { ang } \\
\text { Pendidi } \\
\text { kan } \\
\text { (X1) }\end{array}$ & 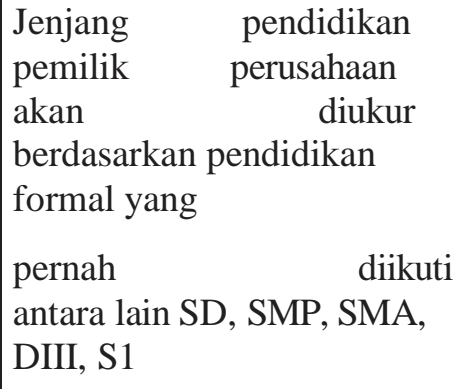 & $\begin{array}{l}\text { Tingkat Pendidikan yang } \\
\text { ditempuh oleh pemilik atau } \\
\text { manajer UMKM antara lain dari } \\
\text { SD, SMA, DIII, S1 dan S2 } \\
\text { (Hariyadi, 2013). }\end{array}$ & Ordinal \\
\hline $\begin{array}{l}\text { Skala Usaha } \\
\text { (X2) }\end{array}$ & $\begin{array}{lr}\text { Skala usaha } & \text { merupakan } \\
\text { kemampuan } & \text { suatu } \\
\text { perusahaan } & \text { dalam } \\
\text { mengelola } & \text { usahanya } \\
\text { berdasarkan } & \text { jumlah } \\
\text { karyawan dan pendapatan } \\
\text { perusahaan dalam kurun } \\
\text { waktu tertentu (Holmes, } \\
\text { 2011) }\end{array}$ & & Ordinal \\
\hline
\end{tabular}

\section{Teknik Pengumpulan Data}

"Menurut Sugiyono (2017) pengertian sumber data adalah Sumber data yang langsung memberikan data kepada pengumpul data". Penelitian ini menggunakan data primer dan data sekunder. Data primer yang digunakan dalam penelitian ini diperoleh secara langsung dari survey yang dilakukan dengan membagikan kuesioner pada UKM di Kecamatan Pamulang Kota Tangerang Selatan. Data sekunder yang digunakan dalam penelitian ini antara lain jumlah UKM di Kecamatan Pamulang Kota Tangerang Selatan per sektor pada tahun 2020 yang diperoleh dari Dinas koperasi dan Usaha Mikro, Kecil dan Menengah Kota Tangerang Selatatan. 


\section{Analisis Data}

Metode penelitian pada dasarnya merupakan cara ilmiah untuk mendapatkan data dengan tujuan dan kegunaan tertentu. Jenis penelitian ini menggunakan metode kuantitatif . Metode kuantitatif sering disebut sebagai metode pasitivistik karena berlandasan pada filsafat positivisme. Metode ini sebagai metode ilmiah/scientific karena telah memenuhi kaidahkaidah ilmiah yaitu konkrit/ empiris, objektif, terukur, rasional, dan sistematis. Metode ini juga disebut metode discovery, karena dengan metode ini ditemukan dan dikembangkan berbagai iptek baru. Metode ini disebut metode kuantitaif karena data dan penelitian berupa angka-angka dan analisis menggunakan statistik. (Sugiyono, 2017)

Analisis data dilakukan dengan menggunakan bantuan program computer yaitu SPSS (software Statistics Product for the Social Science). Ada beberapa teknik analisis data yang digunakan dalam penelitian ini yaitu statistik deskriptif, uji validitas, uji reabilitas, uji asumsi klasik dan uji hipotesis dengan analisis regresi berganda.

\section{E. Uji Hipotesis}

Hipotesis adalah sebuah asumsi atau jawaban sementara mengenai suatu hal. Dalam pengujian hipotesis ini, peneliti menggunakan uji signifikan, dengan penetapan hipotesis nol $(\mathrm{Ho})$ dan hipotesis alternatif $(\mathrm{Ha})$. Hipotesis nol $(\mathrm{Ho})$ adalah suatu hipotesis yang menyatakan bahwa tidak ada pengaruh yang signifikan antara variabel independen dengan variabel dependen sedangkan hipotesis alternatif $(\mathrm{Ha})$ adalah hipotesis yang menyatakan bahwa adanya pengaruh yang signifikan antara variabel independen dengan variabel dependen.

a. Analisis Korelasi Parsial (Uji $t)$

Uji statistik t pada dasarnya menunjukkan seberapa jauh pengaruh suatu variabel penjelas / independen secara individual dalam menerangkan variasi variabel dependen. Uji t dapat dibuktikan dengan melihat nilai signifikansi lebih kecil dari tingkat kepercayaan 5\% atau 0,05 dan atau dapat juga dilihat dari nilai thitung $\geq$ ttabel (Sugiyono, 2017).

1. Perbandingan thitung dengan ttabel

a. Jika $\mid$ thitung $\mid \leq$ ttabel, maka $\mathrm{H} 0$ diterima dan $\mathrm{H} \alpha$ ditolak.

b. Jika $\mid$ thitung $\mid>$ ttabel, maka H0 ditolak dan $\mathrm{H} \alpha$ diterima.

2. Perbandingan nilai signifikansi dengan taraf nyata

a. Jika nilai signifikansi $\geq$ taraf nyata $(0,05)$, maka $\mathrm{H} 0$ diterima dan $\mathrm{H} \alpha$ ditolak.

b. Jika nilai signifikansi $<$ taraf nyata $(0,05)$, maka $\mathrm{H} 0$ ditolak dan $\mathrm{H} \alpha$ diterima.

b. Analisis Korelasi Simultan (Uji $f$ )

Uji $f$ (uji simultan) adalah untuk mengetahui apakah variabel independen secara bersamasama (serentak) mempunyai pengaruh yang signifikan terhadap variabel dependen. Uji statistik yang digunakan pada pengujian simultan adalah uji $f$ atau yang biasa disebut dengan Analysis of varian (ANOVA).

1. Perbandingan thitung dengan ttabel

a. Jika $\mid$ thitung $\mid \leq$ ttabel, maka H0 diterima dan H $\alpha$ ditolak. 73

b. Jika $\mid$ thitung $\mid>$ ttabel, maka $\mathrm{H} 0$ ditolak dan $\mathrm{H} \alpha$ diterima.

2. Perbandingan nilai signifikansi dengan taraf nyata

a. Jika nilai signifikansi $\geq$ taraf nyata $(0,05)$, maka $\mathrm{H} 0$ diterima dan $\mathrm{H} \alpha$ ditolak.

b. Jika nilai signifikansi $<$ taraf nyata $(0,05)$, maka $\mathrm{H} 0$ ditolak dan $\mathrm{H} \alpha$ diterima.

\section{HASIL DAN PEMBAHASAN}

Hasil

\section{A. Populasi dan sampel}

Populasi yang digunakan adalah Usaha Kecil Menengah (UKM) di Kecamatan Pamulang Kota Tangerang Selatan Provinsi Banten yang menurut informasi didapat dari Dinas Koperasi dan Usaha kecil dan Menengah sebanyak 2.215 unit. Karena total populasi yang cukup besar, selanjutnya untuk menentukan sampel menggunakan rumus slovin dengan hasil sebanyak 
96. Kemudian dengan metode Convenience Sampling dari hasil penyebaran kuesioner melalui google form diperoleh sebanyak 68 kuesioner yang bisa di olah.

\title{
B. Analisis Deskriptif
}

\author{
C. Tabel 1
}

D. Analisis Deskriptif

Descriptive Statistics

\begin{tabular}{l|r|r|r|r|r|} 
& N & Minimum & Maximum & Mean & Std. Deviation \\
\hline JP & 68 & 12 & 25 & 19.24 & 2.420 \\
\hline SU & 68 & 21 & 30 & 25.28 & 2.550 \\
\hline PIA & 68 & 23 & 45 & 31.47 & 4.523 \\
\hline Valid N (listwise) & 68 & & & & \\
\hline
\end{tabular}

Sumber : Output SPSS 25.0

Berdasarkan tabel diatas menunjukkan bahwa jumlah responden (n) sebanyak 68 responden. Nilai minimum menunjukkan jawaban responden paling sedikit dan maksimum merupakan jawaban paling tinggi.

\section{Uji Kualitas Data}

\section{Validitas Data}

Dengan tingkat signifikan sebesar 5\%, maka $\mathrm{r}_{\text {tabel }}$ yang digunakan pada penelitian ini adalah 0.235. Hasil pengujian yang dilakukan terhadap pernyataan kuesioner dari variabel indenpenden dan dependen dapat dilihat pada tabel dibawah ini:

\section{Tabel 2}

\section{Hasil Pengujian Validitas X1}

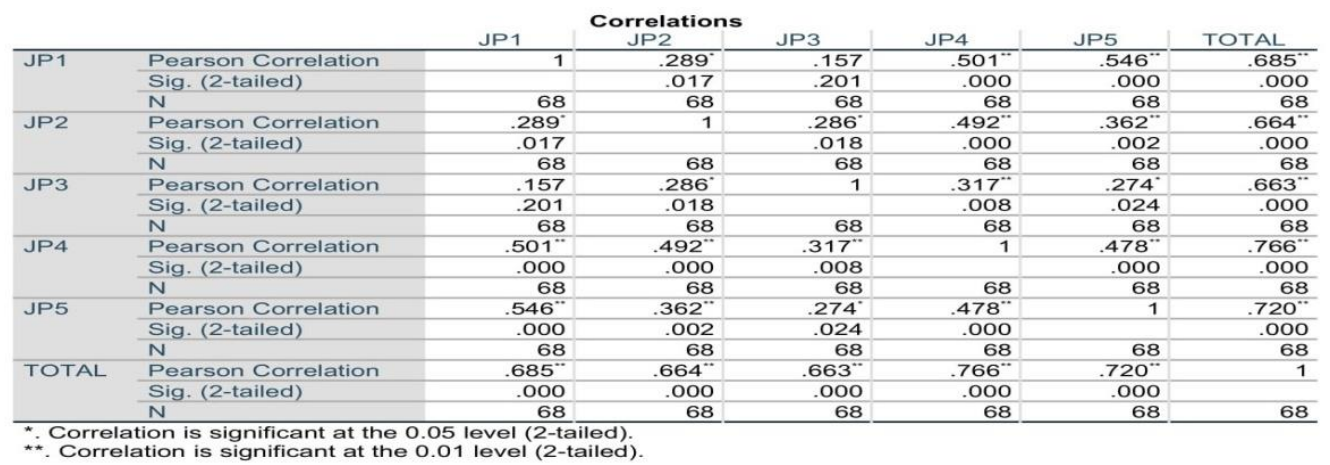

\section{Hasil Pengujian Validitas X2}

\begin{tabular}{|c|c|c|c|c|c|c|c|c|}
\hline \multicolumn{9}{|c|}{ Correlations } \\
\hline & & SU1 & SU2 & SU3 & SU4 & SU5 & SU6 & TOTAL \\
\hline \multirow[t]{3}{*}{ SU1 } & Pearson Correlation & 1 & $.443^{\prime \prime}$ & $.472^{*}$ & $.450 "$ & $.547^{\prime \prime}$ & .432 & $.709^{*}$ \\
\hline & Sig. (2-tailed) & & .000 & .000 & .000 & .000 & .000 & .000 \\
\hline & $\mathrm{N}$ & 68 & 68 & 68 & 68 & 68 & 68 & 68 \\
\hline \multirow[t]{3}{*}{ SU2 } & Pearson Correlation & $.443^{\prime \prime}$ & 1 & $458^{\prime \prime}$ & $628^{* \prime}$ & $.557^{\prime \prime}$ & $.734^{*}$ & $827^{\prime \prime}$ \\
\hline & Sig. (2-tailed) & .000 & & .000 & .000 & .000 & .000 & .000 \\
\hline & $\mathrm{N}$ & 68 & 68 & 68 & 68 & 68 & 68 & 68 \\
\hline \multirow[t]{3}{*}{ SU3 } & Pearson Correlation & .472 & $458^{*}$ & 1 & $.497^{*}$ & $.507^{\prime \prime}$ & $.455^{\prime \prime}$ & $.731^{\prime \prime}$ \\
\hline & Sig. (2-tailed) & .000 & .000 & & .000 & .000 & .000 & .000 \\
\hline & $\mathrm{N}$ & 68 & 68 & 68 & 68 & 68 & 68 & 68 \\
\hline \multirow[t]{3}{*}{ SU4 } & Pearson Correlation & $.450^{\prime \prime}$ & $628^{\prime \prime}$ & $.497^{\prime \prime}$ & 1 & $.497^{\prime \prime}$ & $.563^{*}$ & $.806^{\prime \prime}$ \\
\hline & Sig. (2-tailed) & .000 & .000 & .000 & & .000 & .000 & .000 \\
\hline & $\mathrm{N}$ & 68 & 68 & 68 & 68 & 68 & 68 & 68 \\
\hline \multirow[t]{3}{*}{ SU5 } & Pearson Correlation & $.547^{\prime \prime}$ & $.557^{\prime \prime}$ & $.507^{* \prime}$ & $.497^{* \prime}$ & 1 & $459^{\prime \prime}$ & $.770^{*}$ \\
\hline & Sig. (2-tailed) & .000 & .000 & .000 & .000 & & .000 & .000 \\
\hline & $\mathrm{N}$ & 68 & 68 & 68 & 68 & 68 & 68 & 68 \\
\hline \multirow[t]{3}{*}{ SU6 } & Pearson Correlation & $.432 "$ & $.734^{*}$ & $.455^{\prime \prime}$ & $.563^{* \prime}$ & $.459^{\prime \prime}$ & 1 & $.780^{\circ}$ \\
\hline & Sig. (2-tailed) & .000 & .000 & .000 & .000 & .000 & & .000 \\
\hline & $\mathrm{N}$ & 68 & 68 & 68 & 68 & 68 & 68 & 68 \\
\hline \multirow[t]{3}{*}{ TOTAL } & Pearson Correlation & $.709^{\prime \prime}$ & $.827^{\prime \prime}$ & $.731^{\prime \prime}$ & $.806^{\prime \prime}$ & $.770^{\circ}$ & $.780^{\prime \prime}$ & 1 \\
\hline & Sig. (2-tailed) & .000 & .000 & .000 & .000 & .000 & .000 & \\
\hline & $\mathrm{N}$ & 68 & 68 & 68 & 68 & 68 & 68 & 68 \\
\hline
\end{tabular}




\section{Hasil Pengujian Validitas Y}

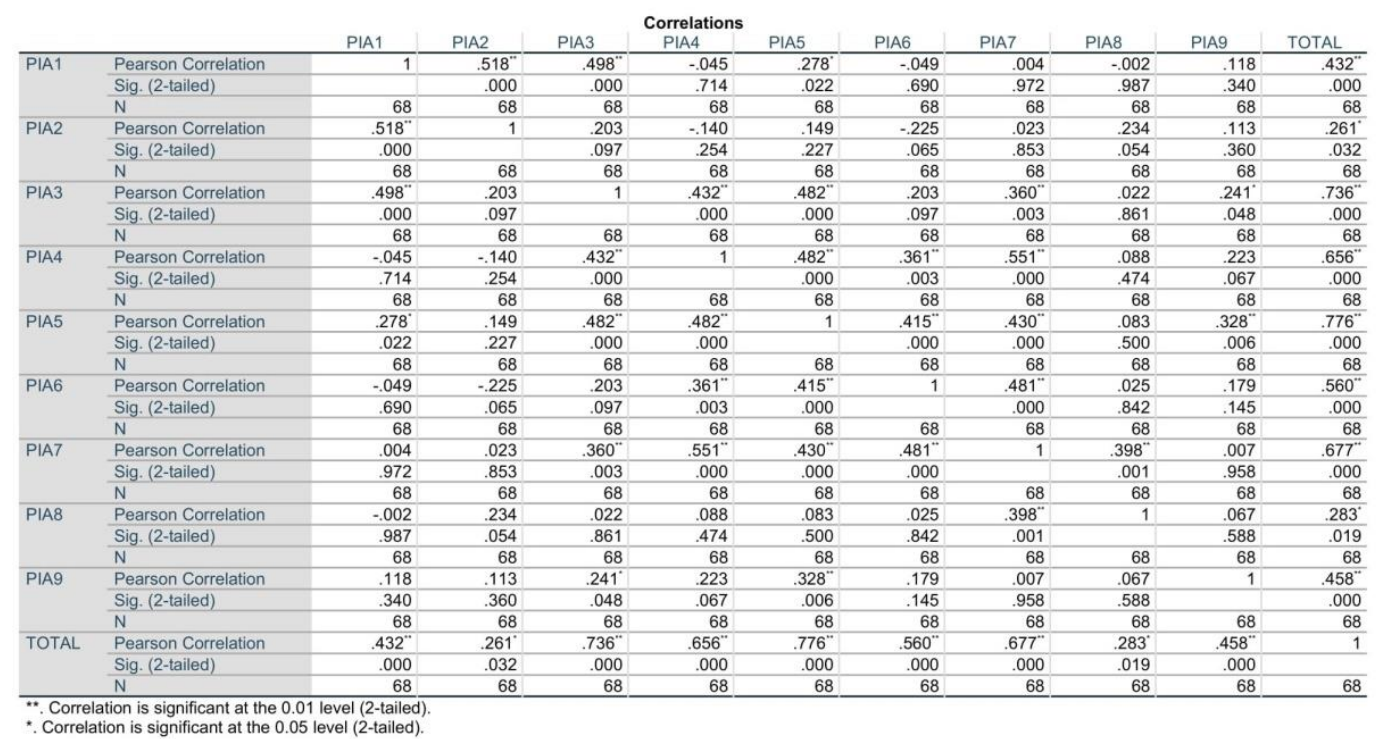

Sumber : Output SPSS 25.0

Berdasarkan hasil uji validitas pada tabel di atas, menunjukkan bahwa semua pernyataan variabel jenjang pendidikan, skala usaha dan pengguna informasi akuntansi adalah valid karena memenuhi kriteria yaitu nilai $r_{\text {hitung }}>r_{\text {tabel }}$.

\section{Uji Realibilitas}

Pada program SPSS versi 25.0, metode ini dilakukan dengan metode Cronbach Alpha, dimana kuesioner dikatakan reliabel jika nilai Cronbach Alpha lebih besar dari 0,60. Berikut ini hasil pengujian reliabilitas pada variabel independen dan dependent.

\section{Tabel 3}

Hasil Uji Realibilitas X1

Item-Total Statistics

\begin{tabular}{l|r|r|r|r} 
& $\begin{array}{c}\text { Scale Mean if } \\
\text { Item Deleted }\end{array}$ & $\begin{array}{c}\text { Scale Variance if } \\
\text { Item Deleted }\end{array}$ & $\begin{array}{c}\text { Corrected Item- } \\
\text { Total Correlation }\end{array}$ & $\begin{array}{c}\text { Cronbach's Alpha } \\
\text { if Item Deleted }\end{array}$ \\
\hline JP1 & 15.50 & 4.015 & .476 & .662 \\
\hline JP2 & 15.32 & 4.252 & .481 & .663 \\
\hline JP3 & 15.84 & 3.690 & .333 & .759 \\
\hline JP4 & 15.15 & 3.948 & .623 & .611 \\
\hline JP5 & 15.13 & 4.176 & .571 & .635 \\
\hline
\end{tabular}

\section{Reliability Statistics}

\begin{tabular}{r|r}
$\begin{array}{c}\text { Cronbach's } \\
\text { Alpha }\end{array}$ & N of Items \\
\hline .712 & 5 \\
\hline
\end{tabular}

\section{Hasil Pengujian Realibilitas X2}

\section{Item-Total Statistics}

\begin{tabular}{lr|r|r|r} 
& $\begin{array}{c}\text { Scale Mean if } \\
\text { Item Deleted }\end{array}$ & $\begin{array}{c}\text { Scale Variance if } \\
\text { Item Deleted }\end{array}$ & $\begin{array}{c}\text { Corrected Item-Total } \\
\text { Correlation }\end{array}$ & $\begin{array}{c}\text { Cronbach's Alpha } \\
\text { if Item Deleted }\end{array}$ \\
\hline SU1 & 20.99 & 4.970 & .591 & .849 \\
\hline SU2 & 21.13 & 4.475 & .735 & .823 \\
\hline SU3 & 21.00 & 4.776 & .605 & .847 \\
\hline SU4 & 21.12 & 4.225 & .678 & .837 \\
\hline SU5 & 21.03 & 4.626 & .655 & .838 \\
\hline SU6 & 21.13 & 4.773 & .683 & .834 \\
\hline \hline
\end{tabular}




\section{Reliability Statistics}

\begin{tabular}{|c|c|c|c|c|}
\hline \multicolumn{2}{|c|}{ Cronbach's Alpha } & $\mathrm{N}$ of Items & & \\
\hline & .862 & 6 & & \\
\hline & & $\begin{array}{r}\text { Hasil Per } \\
\text { Item-Total St: }\end{array}$ & $\begin{array}{l}\text { ujian Realibil } \\
\text { istics }\end{array}$ & as $Y$ \\
\hline & $\begin{array}{l}\text { Scale Mean if } \\
\text { Item Deleted }\end{array}$ & $\begin{array}{c}\text { Scale Variance } \\
\text { if Item } \\
\text { Deleted }\end{array}$ & $\begin{array}{l}\text { Corrected } \\
\text { Item-Total } \\
\text { Correlation }\end{array}$ & $\begin{array}{c}\text { Cronbach's } \\
\text { Alpha if Item } \\
\text { Deleted }\end{array}$ \\
\hline PIA1 & 27.82 & 17.879 & .263 & .726 \\
\hline PIA2 & 27.32 & 19.536 & .155 & .735 \\
\hline PIA3 & 28.03 & 14.238 & .584 & .664 \\
\hline PIA4 & 28.53 & 15.745 & .510 & .683 \\
\hline PIA5 & 28.18 & 14.327 & .657 & .650 \\
\hline PIA6 & 28.68 & 16.222 & .366 & .713 \\
\hline PIA7 & 28.04 & 15.476 & .533 & .678 \\
\hline PIA8 & 27.26 & 19.421 & .176 & .733 \\
\hline PIA9 & 27.90 & 17.616 & .286 & .723 \\
\hline
\end{tabular}

\section{Reliability Statistics}

Cronbach's

\begin{tabular}{r|r} 
Alpha & N of Items \\
\hline .728 & 9 \\
\hline
\end{tabular}

Sumber : Output SPSS 25.0

Berdasarkan tabel di atas, hasil uji reliabilitas pada seluruh variabel mempunyai nilai yang lebih besar dari 0,60. Maka semua variabel - variabel tersebut sudah memenuhi kriteria reliabel.

\section{a. Karakteristik Responden}

Responden pada penelitian ini merupakan pelaku UMKM di kecamatan Pamulang kota Tangerang Selatan. Karakteristik yang diteliti adalah jenis kelamin, riwayat pendidikan, usia, jenis usaha dan pendapatan. Berikut karakteristik responden dapat dilihat pada tabel dibawah ini

\section{Tabel 4}

Karakteristik Responden

\begin{tabular}{ccccc}
\hline No. & Karakteriktik & Keterangan & Jumlah & \% \\
\hline $\mathbf{1}$ & Jenis Kelamin & Laki - laki & 28 & 41 \\
\hline & & Perempuan & 40 & 59 \\
\hline $\mathbf{2}$ & Usia & $<30$ tahun & 32 & 47 \\
\hline & $30-50$ tahun & 25 & 37 \\
\hline & & $>50$ tahun & 11 & 16 \\
\hline 3 & Pendidikan & SD - SMA & 30 & 44 \\
\hline & & S1 & 28 & 41 \\
\hline & S2 & 10 & 15 \\
\hline & S3 & - & -
\end{tabular}




\begin{tabular}{|c|c|c|c|c|}
\hline 4 & Lama Usaha & $<5$ tahun & 26 & 38 \\
\hline & & $5-10$ tahun & 22 & 32 \\
\hline & & $>10$ tahun & 20 & 30 \\
\hline \multirow[t]{4}{*}{5} & Pendapatan & $>1.000 .000$ & 19 & 28 \\
\hline & & $>5.000 .000$ & 22 & 32 \\
\hline & & $>10.000 .000$ & 16 & 24 \\
\hline & & $>15.000 .000$ & 11 & 16 \\
\hline
\end{tabular}

Sumber : Data Primer Diolah (2021)

Berdasarkan tabel 4 diatas dapat diketahui karakteristik responden yang diperoleh dari hasil survey menggunakan kuesioner/angket sejumlah 68 pelaku UMKM. Dari tabel diatas dapat dilihat karakteristik responden dari sisi jenis kelamin didapatkan jumlah responden lakilaki dengan jumlah 28 orang dengan persentase $41 \%$ dan didominasi oleh responden wanita sejumlah 40 orang dengan persentase $59 \%$. Jika dilihat dari usia responden, rata-rata usia didominasi oleh usia $\leq 30$ tahun dengan jumlah responden sejumlah 32 orang $(47 \%)$ dan usia 30 - 50 tahun sejumlah 25 orang (37\%), usia > 50 tahun sejumlah 11 orang (16\%). Jika dilihat dari sisi riwayat pendidikan terakhir, responden di dominasi oleh responden dengan pendidikan dari SD sampai SMA/SMK/MA dengan jumlah 30 orang (44\%), pendidikan S1 sejumlah 28 orang (41\%) dan pendidikan terakhir S2 sejumlah 10 orang (15\%). Sementara untuk omzet atau pendapatan perbulan yang dihasilkan oleh UMKM didominasi dengan omzet berkisar $>1$ juta rupiah dengan jumlah UMKM 19 orang (28\%), > 5 juta rupiah dengan jumlah pelaku UMKM 22 orang $(32 \%),>10$ juta rupiah dengan jumlah pelaku UMKM 16 orang (24\%) dan disusul oleh omzet berkisar 15 juta rupiah keatas dengan jumlah pelaku UMKM 11 orang (16\%).

\section{b. Uji Asumsi Klasik}

Uji normalitas dibuktikan dengan beberapa cara, diantaranya dengan melihat grafik normal p-plot dan tabel.

\section{Gambar 1}

\section{Hasil uji Normalitas P-Plot}

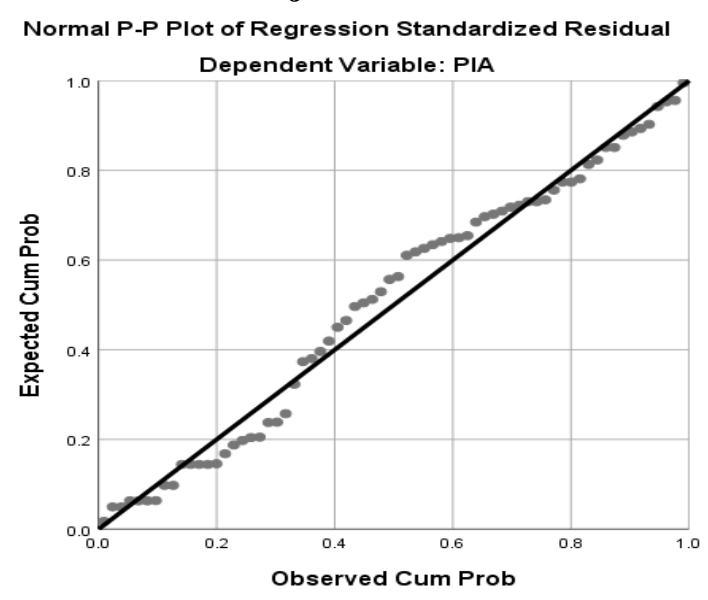

Berdasarkan tampilan uji normalitas dengan p-plot pada gambar 1 diatas dapat dilihat data tersebar disekitar garis diagonal dan mengikuti pola garis diagonal tersebut, maka data tersebut dapat dikatakan berdistribusi normal.

\section{Tabel 5}

Hasil Uji Kolmogorov - Smirnov

\section{One-Sample Kolmogorov-Smirnov Test}


Unstandardized

Residual

\begin{tabular}{llr}
\hline $\mathrm{N}$ & & 68 \\
\hline Normal Parameters & Mean & .0000000 \\
\cline { 2 - 3 } & Std. Deviation & 4.20796345 \\
\hline Most Extreme & Absolute & .097 \\
\cline { 2 - 3 } Differences & Positive & .078 \\
\cline { 2 - 3 } & Negative & -.097 \\
\hline Test Statistic & & .097 \\
\hline Asymp. Sig. (2-tailed) & & $.181^{\mathrm{c}}$ \\
\hline
\end{tabular}

a. Test distribution is Normal.

b. Calculated from data.

c. Lilliefors Significance Correction.

Sumber : Output SPSS 25.0

Berdasarkan tabel diatas menunjukkan bahwa nilai signifikansi menunjukkan angka $0,181>0,05$. Maka data yang digunakan dalam penelitian ini berdistribusi normal menurut uji Kolmogorov-Smirnov.

Uji multikolinearitas dibuktikan dengan melihat nilai tolerance dan Variance Inflation Factor (VIF). Nilai cutoff yang umum digunakan dalam menunjukkan adanya multikolinearitas adalah nilai tolerance $\leq 0.10$ atau nilai VIF $\geq 10$ (Sugiyono, 2017). Dari hasil table 6 maka dapat dikatakan tidak terjadi multikolineritas.

\begin{tabular}{|c|c|c|c|}
\hline \multicolumn{4}{|c|}{$\begin{array}{c}\text { Tabel } 6 \\
\text { Hasil Uji Multikolinearitas } \\
\text { Coefficients }^{\mathrm{a}}\end{array}$} \\
\hline \multirow{2}{*}{\multicolumn{2}{|c|}{ Model }} & \multicolumn{2}{|c|}{ Collinearity Statistics } \\
\hline & & Tolerance & VIF \\
\hline \multirow[t]{3}{*}{1} & (Constant) & & \\
\hline & $\mathrm{JP}$ & .783 & 1.277 \\
\hline & SU & .783 & 1.277 \\
\hline
\end{tabular}

a. Dependent Variable: PIA

Sumber : Output SPSS 25.0

Deteksi terhadap masalah heteroskedastisitas juga dilakukan dengan melihat grafik plot nilai prediksi variabel dependen (ZPRED) dengan residunya variabel independen (SRESID). Uji heteroskedastisitas dalam penelitian ini juga menggunakan uji Glejser dengan nilai signifikansi diatas tingkat kepercayaan $5 \%$ atau 0,05 . Berdasarkan grafik scatterplots yang terlihat pada gambar 2 dibawah menunjukkan bahwa titik-titik menyebar secara acak dan tidak membentuk pola, serta tersebar dibawah maupun diatas angka 0 pada sumbu y. Hal ini dapat disimpulkan bahwa pada data penelitian tersebut tidak terjadi heteroskedastisitas. 


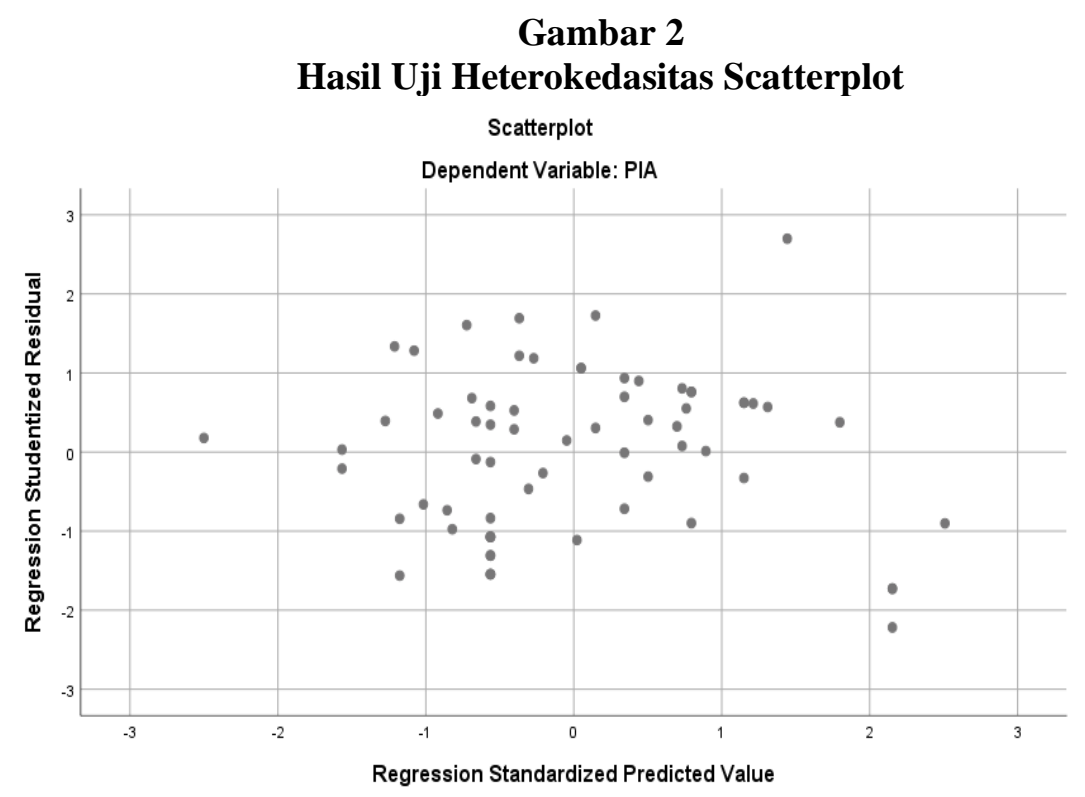

Kemudian uji heteroskedastisitas dalam penelitian ini juga menggunakan uji Park dengan nilai signifikansi diatas tingkat kepercayaan 5\% atau 0,05 dapat dilihat pada tabel 7 dibawah ini :

Tabel 7

\section{Hasil Uji Heterokedasitas Dengan Uji Park Coefficients $^{a}$}

\begin{tabular}{|c|c|c|c|c|c|c|}
\hline \multirow[b]{2}{*}{ Model } & & \multicolumn{2}{|c|}{ Unstandardized Coefficients } & \multirow{2}{*}{$\begin{array}{c}\text { Standardized } \\
\text { Coefficients } \\
\text { Beta }\end{array}$} & \multirow[b]{2}{*}{$\mathrm{t}$} & \multirow[b]{2}{*}{ Sig. } \\
\hline & & B & Std. Error & & & \\
\hline 1 & (Constant) & -8.991 & 9.197 & & -.978 & .332 \\
\hline & Lnx1 & .125 & 2.333 & .007 & .054 & .957 \\
\hline & $\operatorname{Ln} x 2$ & 3.219 & 3.005 & .145 & 1.071 & .288 \\
\hline
\end{tabular}

a. Dependent Variable: Lnei2

Sumber : Output SPSS 25.0

Berdasarkan tabel diatas, bahwa seluruh variabel independen menunjukkan hasil nilai signifikansi diatas 0,05 . Maka dapat disimpulkan secara keseluruhan bahwa data tersebut tidak terjadi heteroskedastisitas.

\section{c. Uji Regresi Berganda}

Uji regresi linier berganda digunakan untuk mencari tahu apakah ada pengaruh yang signifikan antara jenjang pendidikan, skala usaha dan pengguna informasi yang dicari.

\section{Tabel 8}

Uji Regresi Berganda

Coefficients $^{\mathrm{a}}$

\begin{tabular}{|c|c|c|c|c|}
\hline & & \multirow{2}{*}{\multicolumn{2}{|c|}{ Unstandardized Coefficients }} & \multirow{3}{*}{$\begin{array}{c}\text { Standardized } \\
\text { Coefficients } \\
\text { Beta } \\
\end{array}$} \\
\hline \multirow{2}{*}{\multicolumn{2}{|c|}{ Model }} & & & \\
\hline & & B & Std. Error & \\
\hline \multirow[t]{3}{*}{1} & (Constant) & 16.035 & 5.559 & \\
\hline & JP & .590 & .244 & .315 \\
\hline & SU & .162 & .231 & .091 \\
\hline
\end{tabular}

a. Dependent Variable: PIA

Sumber : Output SPSS 25.0

Dari tabel 8 diatas, diperoleh hasil persamaan regresi berganda dengan yang terbentuk adalah:

$\mathrm{Y}=16.035+0.590 \mathrm{X} 1+0.161 \mathrm{X} 2+\mathrm{e}$ 
Dari persamaan tersebut dapat diartikan:

1. Nilai konstanta sebesar 16.035 mengindikasikan bahwa jika variabel independen (jenjang pendidikan dan skala usaha) adalah nol maka pengguna informasi akuntansi akan terjadi sebesar 16.035 .

2. Koefisien regresi variabel jenjang pendidikan (X1) sebesar 0.590 mengindikasikan bahwa setiap kenaikan satu satuan variabel jenjang pendidikan akan meningkatkan pengguna informasi akuntansi sebesar 0,590.

3. Koefisien regresi variabel skala usaha (X2) sebesar 0.161 mengindikasikan bahwa setiap kenaikan satu satuan variabel skala usaha akan meningkatkan pengguna informasi akuntansi sebesar 0.161 .

\section{d. Koefisien Determinasi $\left(\mathbf{R}^{2}\right)$}

Berdasarkan tabel 9 dibawah menyatakan bahwa nilai $\mathrm{R}$ adalah 0,367 atau 36.7\%. Berdasarkan hasil uji koefisien deteminasi pada tabel 9 dibawah menunjukkan bahwa nilai R2 (Adjusted $R$ Square) sebesar 0,108 atau 10,8\%. Sisanya sebesar $89.2 \%$ dipengaruhi oleh variabel lain yang belum diteliti dalam penelitian ini.

\section{Tabel 9}

\section{Hasil Uji Koefisien Determinasi (R2)}

Model Summary

\begin{tabular}{ll|r|r|r} 
Model & R & R Square & \multicolumn{1}{|c|}{$\begin{array}{c}\text { Adjusted R } \\
\text { Square }\end{array}$} & $\begin{array}{l}\text { Std. Error of } \\
\text { the Estimate }\end{array}$ \\
\hline 1 & $.367^{\mathrm{a}}$ & .135 & .108 & 4.272 \\
\hline
\end{tabular}

a. Predictors: (Constant), SU, PJ

Sumber : Output SPSS 25.0

\section{e. Uji T}

Uji statistik t pada dasarnya menunjukkan seberapa jauh pengaruh suatu variabel penjelas / independen secara individual dalam menerangkan variasi variabel dependen. Uji t dapat dibuktikan dengan melihat nilai signifikansi lebih kecil dari tingkat kepercayaan 5\% atau 0,05 dan atau dapat juga dilihat dari nilai thitung $\geq$ ttabel (Sugiyono, 2017).

\begin{tabular}{|c|c|c|c|}
\hline \multicolumn{4}{|c|}{$\begin{array}{c}\text { Tabel } 11 \\
\text { Hasil Uji T } \\
\text { Coefficients }^{\mathrm{a}}\end{array}$} \\
\hline \multicolumn{2}{|c|}{ Model } & $\mathrm{T}$ & Sig. \\
\hline \multirow[t]{3}{*}{1} & (Constant) & 2.885 & .005 \\
\hline & JP & 2.419 & .018 \\
\hline & SU & .700 & .487 \\
\hline
\end{tabular}

a. Dependent Variable: PIA

Sumber : Output SPSS 25.0

Dari hasil analisis uji t diatas dan sekaligus menjawab rumusan masalah yang terdapat pada bab terdahulu sebagai berikut:

Dari hasil analisis menggunakan SPSS 25.0 yang terdapat pada tabel 11 dan sekaligus menjawab rumusan masalah yang terdapat pada bab terdahulu sebagai berikut:

a. Hipotesis pertama:

Berdasarkan tabel 11 pada variabel jenjang pendidikan diperoleh nilai $\mathrm{t}_{\text {hitung }}$ sebesar (2.419). Untuk menentukan distribusi t dicari pada $a=5 \%: 2=2,5 \%$ (uji 2 sisi) dengan derajat bebas $(\mathrm{df})=\mathrm{n}-2$ atau $68-2=66$. Dengan pengujian 2 sisi signifikansi 0,025 (lihat tabel pada lampiran) hasil yang diperoleh untuk $t_{\text {tabel }}$ sebesar 1.997. Dari hasil perhitungan diatas didapatkan nilai jenjang pendidikan $\left(\mathrm{x}_{1}\right)$ memiliki $\mathrm{t}_{\text {hitung }} \geq \mathrm{t}_{\text {tabel }}$ yaitu $2.419 \geq 1,997$ dan nilai signifikansi sebesar $0,018<0,05$. Hal ini dapat diartikan bahwa jenjang pendidikan 
berpengaruh signifikan dan positif terhadap pengguna informasi akuntansi. Maka $\mathrm{H}_{1}$ diterima.

b. Hipotesis kedua:

Berdasarkan tabel 11 pada hasil perhitungan nilai skala usaha $\left(\mathrm{X}_{2}\right)$ diperoleh nilai $\mathrm{t}_{\text {hitung }}$ lebih kecil dari $\mathrm{t}_{\text {tabel }}$ yaitu $0.700<1.997$ dengan nilai signifikansi sebesar $0.487>0.05$. Hal ini menunjukkan bahwa skala usaha tidak berpengaruh signifikan dan negatif terhadap pengguna informasi akuntansi. Maka $\mathrm{H}_{2}$ ditolak.

\section{f. Uji F}

Tabel 10

Hasil Uji F

ANOVA $^{\mathrm{a}}$

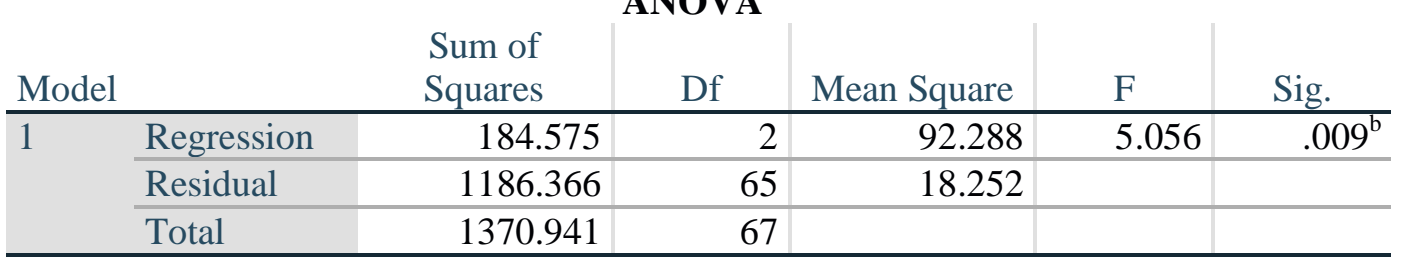

a. Dependent Variable: PIA

b. Predictors: (Constant), SU, PJ

Sumber : Output SPSS 25.0

Berdasarkan tabel 10 diperoleh nilai $\mathrm{F}_{\text {hitung }}$ sebesar 5.056 dengan menggunakan tingkat keyakinan $95 \%$ dan tingkat signifikan 0,05 . Untuk menentukan nilai $\mathrm{F}_{\text {tabel }}$ diperlukan persamaan berikut ini : $\mathrm{df} 1=\mathrm{k}-1 \mathrm{dan} \mathrm{df} 2=\mathrm{n}-\mathrm{k}$

Keterangan: $\quad \mathrm{df}=$ Derajat Bebas

$\mathrm{K}=$ Jumlah Variabel (bebas dan terikat)

$\mathrm{N}=$ Jumlah sampel (responden)

Maka akan didapatkan df $1=3-1=2$ dan df2 $=68-3=65$, hasil diperoleh untuk $\mathrm{F}_{\text {tabel }}$ sebesar 2.75. Jadi jika dibandingkan $\mathrm{F}_{\text {hitung }}>\mathrm{F}_{\text {tabel }}$ yaitu $5.056>2.75$ dan nilai signifikansi $0.009<0,05$ maka dapat disimpulkan bahwa hipotesis ketiga atau $\mathrm{H}_{3}$ diterima.

\section{Pembahasan}

\section{Jenjang Pendidikan Berpengaruh Signifikan Terhadap Pengguna Informasi Akuntansi}

Berdasarkan hasil uji t diatas menunjukkan bahwa variabel jenjang pendidikan berpengaruh signifikan terhadap pengguna informasi akuntansi, hal ini dibuktikan dengan nilai jenjang pendidikan $\left(\mathrm{X}_{1}\right)$ memiliki $\mathrm{t}_{\text {hitung }} \geq \mathrm{t}_{\text {tabel }}$ yaitu $2.419 \geq 1.997$ dan nilai signifikansi sebesar $0.018<0.05$ maka dapat diartikan bahwa jenjang pendidikan berpengaruh signifikan dan positif terhadap pengguna informasi akuntansi. Tingkat pendidikan dikatakan dapat mempengaruhi penggunaan informasi akuntansi apabila tingginya jenjang pendidikan menunjukkan tingginya penggunaan informasi akuntansi dalam perusahaan. Hal tersebut karena ilmu akuntansi diperoleh pada jenjang yang lebih tinggi. Secara logika, orang yang memiliki jenjang pendidikan yang tinggi dianggap lebih cerdas dan mampu menerapkan apa yang telah dipelajari. Semakin tinggi jenjang pendidikan pelaku UMKM, maka dianggap telah mampu menggunakan informasi akuntansi. Karena penggunaan informasi akuntansi mampu memberikan informasi akurat tentang berbagai permasalahan yang terjadi dalam perusahaan dan mampu memberikan solusi tepat waktu.

Informasi akuntansi akan memudahkan perusahaan dalam mengelola laporan keuangannya. Menurut Aufar (2013) menyatakan bahwa jenjang pendidikan berpengaruh terhadap penggunaan informasi akuntansi. Jenjang pendidikan sangat berpengaruh terhadap pemahaman akuntansi disetiap pemilik UMKM yang nantinya akan berpengaruh terhadap persiapan dan kemampuan pemilik UMKM dalam penggunaan informasi akuntansi. Jenjang pendidikan yang rendah membuat pemilik UMKM kurang begitu memahami dalam penggunaan informasi akuntansi dibandingkan dengan pemilik UMKM yang memiliki jenjang pendidikan formal yang lebih tinggi. Semakin tinggi jenjang pendidikan pelaku 
umkm maka semakin banyak informasi yang akan didapat sehingga penggunaa informasi akuntansi akan semakin baik.

Hasil penelitian ini sejalan dengan penelitian sebelumnya yang dilakukan oleh Aufar (2013), Zulkarnaeni \& Rizki (2019); Nirwana \& Purnama (2019) dimana terdapat hubungan positif jenjang pendidikan dengan pengguna informasi akuntansi. Hubungan yang ditunjukkan oleh koefisien regresi adalah positif artinya semakin baik pendidikan maka penggunaan informasi akuntansi akan semakin meningkat.

\section{Skala Usaha Berpengaruh Signifikan Terhadap Pengguna Informasi Akuntansi}

Berdasarkan hasil uji t di dapatkan perhitungan nilai skala usaha $\left(\mathrm{X}_{2}\right)$ diperoleh nilai thitung lebih kecil dari ttabel yaitu $0.700<1.997$ dengan nilai signifikansi sebesar $0.487>$ 0.05. Hal ini menunjukkan bahwa skala usaha tidak berpengaruh signifikan terhadap pengguna informasi akuntansi.

Variabel skala usaha memiliki variasi yang sangat tinggi atau bersifat heterogen, apabila dihubungkan dengan variabel penggunaan informasi akuntansi yang bersifat homogen, akan berakibat pada hubungan yang tidak signifikan. Sehingga, dapat disimpulkan bahwa hipotesis kedua yang menyatakan bahwa variabel skala usaha tidak berpengaruh signifikan terhadap pengguna informasi akuntansi pada UMKM di Kecamatan Pamulang ditolak. Skala usaha berhubungan dengan teori cost volume profit analysis. Menurut Blocher et al. (2009: 387), cost volume profit analysis merupakan metode untuk menganalisis bagaimana keputusan operasi dan keputusan pemasaran mempengaruhi laba bersih berdasarkan pemahaman tentang hubungan antara biaya variabel, biaya tetap, harga jual per unit, dan tingkat output. Melalui analisis tersebut, perusahaan dituntut untuk mengetahui berapa biaya tetap dan biaya variabel yang dikeluarkan oleh perusahaan yang disebut dengan biaya total atau total cost serta berapa unit yang harus dijual perusahaan dan berapa harga jual produk agar perusahaan berada dalam kondisi memperoleh keuntungan. Oleh karena itu, perusahaan dapat menyikapinya dengan menggunakan informasi akuntansi agar dapat mengetahui berapa penjualan yang harus dicapai dan berapa harga jual yang layak agar mampu memperoleh keuntungan maksimal.

Dalam hal ini, UMKM di Kecamatan Pamulang masih belum menggunakan informasi akuntansi dengan memadai karena UMKM yang digunakan sebagai sampel sebagian besar berskala mikro. Sehingga, penggunaan informasi akuntansi belum maksimal dan belum konsisten. Hasil penelitian ini konsisten dengan hasil penelitian Sriwahyuni et al. (2016) menjelaskan bahwa skala usaha tidak memiliki pengaruh signifikan dan negatif terhadap pengguna informasi akuntansi.

2. Jenjang Pendidikan dan Skala Usaha secara bersama sama Mempengaruhi Penggunaan Informasi Akuntansi

Berdasarkan hasil uji $\mathrm{F}$ diperoleh nilai $\mathrm{F}_{\text {hitung }}$ sebesar 5.056 dengan menggunakan tingkat keyakinan 95\% dan tingkat signifikan 0,05. Jika dibandingkan $\mathrm{F}_{\text {hitung }}>\mathrm{F}_{\text {tabel }}$ yaitu $5.056>$ 2.75 dan nilai signifikansi $0.009<0,05$ maka dapat disimpulkan bahwa hipotesis ketiga atau $\mathrm{H}_{3}$ diterima bahwa jenjang pendidikan dan skala usaha secara ber sama sama mempengaruhi penggunaan Informasi Akuntansi terbukti signifikan. Hal ini berarti semakin tinggi jenjang pendidikan pemilik dan semakin besar skala usaha mendorong pemilik UMKM untuk mempergunakan informasi akuntansi.

\section{SIMPULAN}

Berdasarkan dari hasil Uji t menunjukkan bahwa variabel jenjang pendidikan berpengaruh signifikan terhadap pengguna informasi akuntansi, hal ini membuktikan bahwa apabila semakin tinggi latar belakang pendidikan semakin baik penggunaan informasi akuntansi. Seseorang yang memiliki pendidikan yang berkaitan dengan akuntansi tentu memiliki pengetahuan akuntansi tentang penggunaan informasi akuntansi dan memahami pentingnya menggunakan informasi akuntansi dalam pengambilan keputusan yang berkaitan dengan aktivitas nya, dan juga sebagai fungsi pengawasan. Berbeda dengan hasil uji t untuk 
variabel skala usaha yang menunjukkan tidak terdapat pengaruh terhadap penggunaan informasi akuntansi. Hasil uji F juga menunjukkan bahwa terdapat hubungan secara bersama sama antara jenjang pendidikan dan skala usaha terhadap penggunaan sistem informasi.

\section{DAFTAR PUSTAKA}

Pengertian, Jenis dan Perkembangan UMKM di Indonesia. https://www.jurnal.id/id/blog/pengertian-jenis-dan-perkembangan-umkm-di-indonesia/ . Diakses pada tanggal 22 Maret 2021.

Santia, T. 4 september 2020. "Berapa Jumlah UMKM di Indonesia? Ini Hitungannya". https://www.liputan6.com/bisnis/read/4346352/berapa-jumlah-umkm-di-indonesia-inihitungannya\#: :text=Menurut\%20Badan\%20Pusat\%20Statistik\%20(BPS, usaha\%20yan g \%20beroperasi\%20di\%20Indonesia. Diakses pada 20 Oktober 2020.

Permana, A. 3 Januari 2020. "Inilah 8 Permasalahan UMKM Yang Sering Terjadi". https://seoanaksholeh.com/bisnis/permasalahan-umkm. Diakses pada 20 oktober 2020

Nirwana, A., \& Purnama, D. (2019). Pengaruh Jenjang Pendidikan, Skala Usaha Dan Lama Usaha Terhadap Penggunaan Informasi Akuntansi Pada Umkm Di Kecamatan Ciawigebang. Jurnal Riset Keuangan Dan Akuntansi, 5(1), 55-65. https://doi.org/10.25134/jrka.v5i1.1881

Depdiknas .2003. Undang-undang RI No.20 tahun 2003.tentang sistem pendidikan nasional.

Holmes, S \& Nicholls. 1988. An Analysis Of The Use Of Accounting Informationby Australian Small Business. Journal of small business management, 26(20). 57-68

Aufar, A. 2013. Faktor-Faktor Yang Mempengaruhi Penggunaan Informasi Akuntansi Pada UMKM (Usaha Kecil dan Menengah) (Survei Pada Perusahaan Rekanan PT. PLN (Persero) di Kota Bandung). Jurnal Ilmiah, Universitas Widyatama. Bandung

Zulkarnnaeni, A. S., \& Rizki, N. C. (2019). Pengaruh Pendidikan Terakhir, Skala Usaha Dan Pelatihan Akuntansi Terhadap Penggunaan Informasi Akuntansi Pada Ukm (Studi Empiris Terhadap Ukm Di Desa Kedensari, Kecamatan Tanggulangin Kabupaten Sidoarjo). JIAI (Jurnal Ilmiah Akuntansi Indonesia), 4(2), 166-174. https://doi.org/10.32528/jiai.v4i2.2662

Novianti, D., Mustika, I. W., \& Eka, L. H. (2018). Pengaruh Tingkat Pendidikan, Pelatihan Akuntansi, Umur Usaha Dan Skala Usaha Pelaku UMKM Terhadap Penggunaan Informasi Akuntansi Di Kecamatan Purwokerto Utara. Jurnal Ekonomi, Bisnis, Dan Akuntnasi (JEBA), 20(3), 1-14

Sriwahyuni,. D.R, Fatahurrazak,. \& Munthe, I.L.S. 2016. Faktor-faktor yang mempengaruhi penggunaan informasi akuntansi pada Usaha Mikro, Kecil dan Menengah (UMKM) yang ada di Kota Tanjungpinang. Universitas Maritim Raja Ali Haji

Tambunan, F. 2019. PENGARUH PENGETAHUAN AKUNTANSI DAN PENGALAMAN USAHA TERHADAP PENGEMBANGAN USAHA DAN PENGGUNAAN INFORMASI AKUNTANSI SEBAGAI VARIABEL INTERVENING (Kajian Empiris Pada Pelaku Usaha Kecil dan Menengah di Kelurahan Tanjung Rejo Kecamatan Medan Sunggal). AT-TAWASSUTH: Jurnal Ekonomi Islam, Volume IV No. 2 Juli - Desember 2019: $371-394$.

Andriani, N, \& Zuliyati. 2015. FAKTOR-FAKTOR YANG MEMPENGARUHI PENGGUNAAN INFORMASI AKUNTANSI (STUDI PADA UMKM KAIN TENUN IKAT TROSO JEPARA). Prosiding Seminar Nasional Kebangkitan Teknologi Tahun 2015.

Undang-Undang No 20 Tahun 2008 Tentang Usaha Mikro, Kecil dan Menengah (UMKM).

Amalia, D. 1 februari 2020. Keunggulan Usaha Micro, Kecil dan Menengah. https://www.jurnal.id/id/blog/pengertian-jenis-dan-perkembangan-umkm-di-indonesia/ . Diakses pada 27 oktober 2020.

Nafsiah, S.N., dan Birahma, R. Y. 2019. Faktor-Faktor Yang Mempengaruhi Penggunaan Informasi Akuntansi Pada UMKM(Survei Perusahaan Umkm Pdam Tirta Sejiran Setason Kab. Bangka Barat). Universitas Bina Darma. Palembang. 
Shayful, Bahri. 2016. "Pengantar Akuntansi Berdasarkan SAK ETAP dan IFRS. Edisi 1. Yogyakarta.

Efriyenty, D. 2020. ANALISIS FAKTOR-FAKTOR YANG MEMENGARUHI PENGGUNAAN INFORMASI AKUNTANSI PADA UMKM KOTA BATAM. Jurnal Bisnis Terapan. Volume no 04 nomor 01.

Astuti. 2014. Pengaruh karakteristik internal perusahaan terhadap penyiapan dan penggunaan informasi akuntansi perusahaan kecil dan menengah di kabupaten kudus. Diponegoro Journal of Accounting, 2(4), 14-22.

Holmes, Scott, N. 2011. Accounting Information by Australian Small Busines. Journal Of Small Business Management. University Of Newcastle.

Sunaryo, Dede., Dadang \& Erdawati,L,. 2021. PENGARUH PERSEPSI PELAKU USAHA MIKRO KECIL DAN MENENGAH TENTANG AKUNTANSI, PENGETAHUAN AKUNTANSI, DAN SKALA USAHA TERHADAP PENGGUNAAN INFORMASI AKUNTANSI. Competitive Jurnal Akuntansi dan Keuangan, Vol. 5 (No.1),E-ISSN 2549-79IX

Wibowo, Alex dan Kurniawati, E. P,. 2015. PENGARUH PENGGUNAAN INFORMASI AKUNTANSI TERHADAP KEBERHASILAN USAHA KECIL MENENGAH(STUDI PADA SENTRA KONVEKSI DI KECAMATAN TINGKIR KOTA SALATIGA. Jurnal Ekonomi dan Bisnis. Volume 18 nomor 2.

Hariyadi. 2013. Faktor-faktor yang mempengaruhi penggunaan informasi akuntansi pada usaha mikro, kecil dan menengah (UMKM) yang bergerak di bidang jenis usaha makanan di kota Tanjungpinang. Diponegoro Journal of Accounting, 2(3), 1-13.

Holmes, Scott, N. 2011. Accounting Information by Australian Small Busines. Journal Of Small Business Management. University Of Newcastle.

Sugiyono. 2017. Metode Penelitian Kuantitatif, Kualitatif, dan R\&D. Bandung : Alfabet

Blocher, E.J. et al. 2009. Manajemen biaya: Penekanan strategis (buku 1, edisi ketiga). Alih bahasa oleh Tim Penerjemah Penerbit Salemba. Jakarta: Salemba Empat. 